\title{
Tumour Necrosis Factor-alpha and Nuclear Factor-kappa B Gene Variants in Sepsis
}

\author{
Leyla Acar1, Nazan Atalan², E. Hande Karagedik1, Arzu Ergen1 \\ ${ }^{1}$ Department of Molecular Medicine, İstanbul University Institute of Experimental Medicine, İstanbul, Turkey \\ ${ }^{2}$ Clinic of Anesthesia and Reanimation, Siyami Ersek Thoracic Cardiovascular Surgery Training and Research Hospital, İstanbul, Turkey
}

Background: The humoral system is activated and various cytokines are released due to infections in tissues and traumatic damage. Nuclear factor-kappa B dimers are encoded by nuclear factor-kappa B genes and regulate transcription of several crucial proteins of inflammation such as tumour necrosis factor-alpha.

Aims: To investigate the possible effect of polymorphisms on tumour necrosis factor-alpha serum levels with clinical and prognostic parameters of sepsis by determining the nuclear factor-kappa B-1-94 ins/ del ATTG and tumour necrosis factor-alpha (-308 G/A) gene polymorphisms and tumour necrosis factor-alpha serum levels.

Study Design: Case-control study.

Methods: Seventy-two patients with sepsis and 104 healthy controls were included in the study. In order to determine the polymorphisms of nuclear factor-kappa B-1-94 ins/del ATTG and tumour necrosis factor-alpha (-308 G/A), polymerase chain reaction-restriction fragment length polymorphism analysis was performed and serum tumour necrosis factor-alpha levels were determined using an enzyme-linked immunosorbent assay.

Results: We observed no significant differences in tumour necrosis factor-alpha serum levels between the study groups. In the patient group, an increase in the tumour necrosis factor-alpha serum levels in patients carrying the tumour necrosis factor-alpha (-308 G/A) A allele compared to those without the A allele was found to be statistically significant. Additionally, an increase in the tumour necrosis factor-alpha serum levels in patients carrying tumour necrosis factor-alpha $(-308 \mathrm{G} / \mathrm{A}) \mathrm{AA}$ genotype compared with patients carrying the AG or GG genotypes was statistically significant. No significant differences were found in these 2 polymorphisms between the patient and control groups ( $p>0.05$ ).

Conclusion: Our results showed the AA genotype and the A allele of the tumour necrosis factor-alpha ( -308 G/A) polymorphism may be used as a predictor of elevated tumour necrosis factor-alpha levels in patients with sepsis.

Keywords: Sepsis, polymorphism, tumor necrosis factor-alpha, NF-kappa B

Address for Correspondence: Dr. Arzu Ergen, Department of Molecular Medicine, İstanbul University Institute of Experimental Medicine, İstanbul, Turkey e-mail: a_ergen@yahoo.com - aergen@istanbul.edu.tr_ORCID ID: orcid.org/0000-0001-5736-8453

Received: 24 February 2017 Accepted: 24 August 2017 • DOI: 10.4274/balkanmedj.2017.0246

Available at www.balkanmedicaljournal.org

Cite this article as:

Acar L, Atalan N, Karagedik EH, Ergen A. Tumour Necrosis Factor-alpha and Nuclear Factor-kappa B Gene Variants in Sepsis. Balkan Med J 2018;35:30-5

${ }^{\circ}$ Copyright 2018 by Trakya University Faculty of Medicine / The Balkan Medical Journal published by Galenos Publishing House. 
Sepsis is a multisystem disease typically causing hemodynamic alterations, shock, organ dysfunction, and organ failure. Moreover, sepsis can be life threatening. Studies have shown that the humoral system is activated and various cytokines are released due to infections in tissues and traumatic damage (1). Nuclear factor-kappa B (NF-кB) dimers, which are encoded by $\mathrm{NF}-\kappa \mathrm{B}$ genes, regulate transcription of several crucial proteins of inflammation such as tumour necrosis factor-alpha (TNF- $\alpha$ ) (2). Additionally, NF- $\kappa \mathrm{B}$ is a key molecule in the immune and inflammatory response; in many cell types it modulates cell proliferation, apoptosis, adhesion, invasion and angiogenesis (3). The major form of NF- $\kappa B$ is a heterodimer of the $\mathrm{p} 50$ and p65/RelA subunits encoded by genes NF-кB1 and RelA (4). -94 ins/del ATTG rs28362491 polymorphism was identified between 2 main promoter regulatory elements in the NF- $\kappa$ B1 gene. ATTG deletion leads to the loss of binding to nuclear proteins, which causes decreased promoter activity (2). ATTG deletion leads to the loss of binding to nuclear proteins, which causes decreased promoter activity. Studies report that the ATTG deletion is associated with immune and inflammatory diseases (2). Schäfer et al. (5) suggested that hydrocortisone therapy in D allele carriers of the NF- $\kappa$ B1-94 ins/del ATTG polymorphism was a prognostic factor for 30-day mortality. TNF- $\alpha$ is one of the major mediators of the immune response against infectious challenge. Increased levels of TNF- $\alpha$ have been found in sepsis, but TNF- $\alpha$ inhibition has proven to be an unsuccessful treatment (6). The main source of TNF- $\alpha$ synthesis is human monocytes. Plasma levels of TNF- $\alpha$ are normally minimal; however, cells of the immune system release TNF- $\alpha$ on stimulation. The correlation between TNF- $\alpha$ and inflammatory process-based pathologic states has been previously investigated. In healthy volunteers and patients with septic shock, elevated TNF- $\alpha$ plasma levels have been reported after endotoxin excitation (7). Several polymorphisms have been identified at different positions of the TNF- $\alpha$ promoter region in various infectious and inflammatory diseases $(8,9)$, mainly focusing on the promoter single nucleotide polymorphism TNF- $\alpha-308 \mathrm{G} / \mathrm{A}$ in sepsis. Although many studies have reported the association of the A allele with susceptibility to septic shock, the findings have been variable $(10,11)$. The $\mathrm{G} / \mathrm{A}$ transition at position -308 in the TNF- $\alpha$ promoter has been reported to affect TNF promoter activity and TNF- $\alpha$ production (12). In a meta-analysis, Zhang et al. (13) reported that TNF- $\alpha-308 \mathrm{G} / \mathrm{A}$ and $-238 \mathrm{G} / \mathrm{A}$ polymorphisms were associated with an increased risk of sepsis but not sepsis-related mortality.

The aim of this study was investigate the possible effects of NF- $\kappa$ B1 -94 ins/del ATTG and TNF- $\alpha$ (-308 G/A) gene polymorphisms on TNF- $\alpha$ serum levels and clinical parameters of sepsis in Turkish sepsis patients.

\section{MATERIALS AND METHODS}

\section{Study groups}

The study group consisted of 72 patients (21 women and 51 men; mean age $64.60 \pm 11.45$ years) diagnosed with sepsis in between February 2014 and February 2015. Sepsis was defined in accordance with Bone et al. (14). The control group included 104 randomly selected healthy individuals (20 women, 84 men; mean age $62.28 \pm 11.34$ years) who had no signs of sepsis. All participants gave written informed consent. This study was approved by the local ethics committee (February 20, 2014; number: 380) and was carried out in concordance with the Declaration of Helsinki.

\section{DNA isolation}

Peripheral blood of participants was collected in EDTAcontaining vacurtainer tubes (BD Vacutainer, Franklin Lakes, NJ., USA) Genomic DNA was extracted in accordance with PureLink ${ }^{\circledR}$ Genomic Kit manufacturer's instructions (Invitrogen, Carlsbad, CA, USA).

\section{Genotyping for NF-кB1-94 ins/del ATTG and TNF $\alpha(-308$ G/A) polymorphisms}

The NF-кB1 -94 ins/del ATTG and TNF- $\alpha-308 \mathrm{G} / \mathrm{A}$ polymorphisms were amplified and genotyped using polymerase chain reaction-restriction fragment length polymorphism (PCR-RFLP). The genotype of the $N F-\kappa B 1$ gene polymorphism was amplified using the following primer sequences: F- 5'-TTT AAT CTG TGA AGA GAT GTG AAT G -3', R- 5'- CTC TGG CTT CCT AGC AGG G -3' and the genotype of the TNF- $\alpha-308$ G/A gene polymorphism was amplified using the following primer sequences: F- 5'-AGG CAA TAG GTT TTG AGG GCC AT -3', R- 5'- TCC TCC CTG CTC CGA TTC CG -3'.

PCR was performed for the $N F-\kappa B 1$ gene with the initial denaturation at $95^{\circ} \mathrm{C}$ for 5 minutes, 38 cycles at $94^{\circ} \mathrm{C}$ for 45 seconds, $72{ }^{\circ} \mathrm{C}$ for 45 seconds and the final step at $72{ }^{\circ} \mathrm{C}$ for 5 minutes. PCR products were then digested using the Van91I restriction enzyme for 3 hours at $37^{\circ} \mathrm{C}$. Three genotypes were determined through distinct banding patterns as base pairs (bp) on a $2 \%$ agarose gel for the $N F-\kappa B 1$ gene polymorphism: homozygous del/del (254 bp), heterozygous ins/del (254 and $206 \mathrm{bp}$ ) and homozygous ins/ins (206 bp).

For the TNF- $\alpha-308$ G/A polymorphism, PCR was performed with the initial denaturation at $95^{\circ} \mathrm{C}$ for 5 minutes, 35 cycles of $94{ }^{\circ} \mathrm{C}$ for 45 seconds, $64{ }^{\circ} \mathrm{C}$ for 45 seconds, $72^{\circ} \mathrm{C}$ for 45 seconds and the final step at $72^{\circ} \mathrm{C}$ for 5 minutes. The PCR products were digested using the NcoI restriction enzyme for 3 hours at 37 ${ }^{\circ} \mathrm{C}$. Three genotypes were determined through distinct banding patterns on a $2 \%$ agarose gel for the TNF- $\alpha$ gene polymorphism: 
$107 \mathrm{bp}$ for the AA genotype, 20 and $87 \mathrm{bp}$ for the GG genotype, and 20, 87 and $107 \mathrm{bp}$ for the AG genotype.

\section{Determination of TNFa levels}

Fasting blood samples were obtained from each participant in plain tubes (Vacuette). The samples were centrifuged for 10 minutes at $1500 \times \mathrm{g}$ followed by the removal of serum. Levels of TNF- $\alpha$ were determined using a human ELISA kit (Diaclone, Besancon Cedex, France) in Greiner Labortechnik, Germany, accordance with the manufacturer's protocol.

\section{Statistical analysis}

The statistical analyses were performed using the SPSS software version 21.0 (SPSS, Chicago, Illinois, USA). P values less than 0.05 were assumed to be statistically significant. The differences in allele and genotype frequencies between patient and control groups were detected using the $\chi^{2}$ and Fisher test. We compared the biochemical parameters in the case and the control groups using the Student's t-test. Biochemical parameters among the genotypes were investigated using One-Way ANOVA and the Mann-Whitney U test.

\section{RESULTS}

\section{Biochemical and demographical analysis}

Biochemical and demographic data of the study groups are given in Table 1. No statistical difference was found in terms

TABLE 1. Biochemical and demographic parameters of the study population

\begin{tabular}{|c|c|c|c|}
\hline Parameters & Patients $(n=72)$ & Controls $(n=104)$ & $\mathrm{p}$ value \\
\hline Age (years) & $64.60 \pm 11.45$ & $62.28 \pm 11.34$ & $>0.05$ \\
\hline Temperature $\left({ }^{\circ} \mathrm{C}\right)$ & $37.02 \pm 1.02$ & $36.49 \pm 0.13$ & $<0.001$ \\
\hline Creatinine (mg/dL) & $2.17 \pm 1.50$ & $0.97 \pm 0.34$ & $<0.001$ \\
\hline $\begin{array}{l}\text { Blood urea nitrogen } \\
(\mathrm{mg} / \mathrm{dL})\end{array}$ & $62.79 \pm 28.96$ & $20.65 \pm 5.89$ & $<0.001$ \\
\hline Hemoglobin (g/dL) & $9.65 \pm 1.11$ & $13.28 \pm 1.72$ & $<0.001$ \\
\hline WBC $\left(\mathrm{kg} / \mathrm{mm}^{3}\right)$ & $20714.43 \pm 14737.03$ & $7735.87 \pm 2253.08$ & $<0.001$ \\
\hline $\begin{array}{l}\text { C-reactive protein } \\
(\mathrm{mg} / \mathrm{L})\end{array}$ & $17.90 \pm 5.26$ & $0.50 \pm 0.05$ & $<0.001$ \\
\hline $\mathrm{pH}$ & $7.35 \pm 0.10$ & $7.42 \pm 0.31$ & $<0.001$ \\
\hline Lactate $(\mathrm{mEq} / \mathrm{L})$ & $4.00 \pm 3.75$ & $1.02 \pm 0.44$ & $<0.001$ \\
\hline Glucose (mg/dL) & $163.02 \pm 63.51$ & $116.14 \pm 37.33$ & $<0.001$ \\
\hline $\mathrm{K}^{+}(\mathrm{mEq} / \mathrm{L})$ & $4.06 \pm 0.86$ & $3.86 \pm 0.43$ & $>0.05$ \\
\hline SGOT & $513.78 \pm 98.96$ & $28.40 \pm 22.09$ & $<0.001$ \\
\hline SGPT & $244.82 \pm 51.20$ & $28.16 \pm 26.73$ & $<0.001$ \\
\hline $\begin{array}{l}\text { Lactate } \\
\text { dehydrogenase }\end{array}$ & $483.23 \pm 268.16$ & $220.94 \pm 92.91$ & $<0.001$ \\
\hline TNF- $\alpha$ level (pg/mL) & $49.47 \pm 24.79$ & $47.94 \pm 21.02$ & $>0.05$ \\
\hline \multicolumn{4}{|c|}{$\begin{array}{l}\mathrm{n} \text { : number of individuals; } \mathrm{pH} \text { : acidity; SGOT: serum glutamic oxaloacetic } \\
\text { transaminase; SGPT: serum glutamic pyruvic transaminase; WBC: white blood cell; } \\
\text { TNF- } \alpha \text { : tumour necrosis factor-alpha; Statistical evaluation was performed using the } \\
\text { Student's t-test }\end{array}$} \\
\hline
\end{tabular}

of age between the patient and the control groups $(\mathrm{p}>0.05)$. As expected, body temperature, creatinine, blood urea nitrogen (BUN), white blood cells (WBC), C-reactive protein (CRP), $\mathrm{pH}$, lactate, glucose, lactate dehydrogenase, serum glutamicoxaloacetic transaminase (SGOT), serum glutamic-pyruvic transaminase $\left(\right.$ SGPT) $(\mathrm{p}<0.001)$ and $\mathrm{K}^{+}(\mathrm{p}=0.043)$ levels are higher in the sepsis group compared to the controls.

\section{Genetic analysis}

Between the study groups, there were no significant findings in terms of the $N F-\kappa B 1-94$ ins/del ATTG and TNF- $\alpha(-308 \mathrm{G} / \mathrm{A})$ polymorphism genotypes and allele distributions (Table 2).

\section{Hardy-Weinberg equilibrium}

Each of the case and control groups was checked for all polymorphisms using Hardy-Weinberg equilibrium, and the equilibrium was confirmed by PLINK software using the exact test (for patients $N F-\kappa B 1 \mathrm{p}=0.006$, TNF- $\alpha \mathrm{p}=0.02$; for controls $N F-\kappa B 1 \mathrm{p}=0.001, \mathrm{TNF}-\alpha \mathrm{p}=0.38)$.

Serum TNF- $\alpha$ levels according to $N F-\kappa B 1-94$ ins/del ATTG and TNF- $\alpha$ (-308 G/A) genotypes and allele distributions in the study groups are shown in Table 3. In the patient group, increased TNF- $\alpha$ serum levels in patients carrying the TNF- $\alpha$ (-308 G/A) A allele compared with those without the A allele were found to be statistically significant. Additionally, increased TNF- $\alpha$ serum levels in patients carrying TNF- $\alpha(-308$ G/A) AA genotype was statistically significant when compared to patients carrying the GA genotype [95\% CI: (10.71-71.66);

TABLE 2. Distribution of NF- $\kappa$ B1 -94 ins/del ATTG and TNF- $\alpha$ (-308 G/A) genotype and alleles in the study groups

\begin{tabular}{|c|c|c|}
\hline $\mathrm{NF}-\kappa \mathrm{B} 1$ & Patients $(n=72)$ & Controls $(n=104)$ \\
\hline \multicolumn{3}{|c|}{ Genotype } \\
\hline ins/ins & $12(16.7 \%)$ & $23(22.1 \%)$ \\
\hline $\mathrm{del} / \mathrm{del}$ & $39(54.2 \%)$ & $58(55.8 \%)$ \\
\hline ins/del & $21(29.2 \%)$ & $23(22.1 \%)$ \\
\hline \multicolumn{3}{|l|}{ Alleles } \\
\hline ins & $45(31.2 \%)$ & $69(33.2 \%)$ \\
\hline del & $99(68.8 \%)$ & $139(66.8 \%)$ \\
\hline TNF- $\alpha$ & Patients $(n=72)$ & Controls $(n=104)$ \\
\hline \multicolumn{3}{|c|}{ Genotype } \\
\hline GG & $58(80.6 \%)$ & $84(80.8 \%)$ \\
\hline AA & $3(4.2 \%)$ & $2(1.9 \%)$ \\
\hline GA & $11(15.3 \%)$ & $18(17.3 \%)$ \\
\hline \multicolumn{3}{|l|}{ Alleles } \\
\hline G & $127(88.2 \%)$ & $186(89.4 \%)$ \\
\hline A & $17(11.8 \%)$ & $22(10.6 \%)$ \\
\hline $\begin{array}{l}\mathrm{n} \text { : numbe } \\
\text { factor-kap }\end{array}$ & Ir necrosis facto & a; NF-кB1: nuclear \\
\hline
\end{tabular}


$\mathrm{p}=0.009]$ and $\mathrm{GG}[\mathrm{p}=0.002$, 95\% CI: (16.92-72.33)]. When comparing $N F-\kappa B 1$-94 ins/del ATTG, TNF- $\alpha$ (-308 G/A) genotype and allele distributions in the control group, no significant difference between TNF- $\alpha$ levels was found. TNF- $\alpha$ levels in terms of NF-kB1 -94 ins/del ATTG polymorphism were determined as ins/ins $>$ ins/del $>\mathrm{del} / \mathrm{del}$, and TNF $\alpha$ levels in terms of TNF- $\alpha$ (-308 G/A) polymorphism were determined as AA $>$ GA $>$ GG respectively. We also detected TNF- $\alpha$ levels by infectious agent (Table 4). In patients, TNF- $\alpha$ levels increased

\begin{tabular}{|c|c|c|}
\hline $\begin{array}{l}N F-k B 1-94 \text { ins/del } \\
\text { ATTG polymorphism }\end{array}$ & $\begin{array}{c}\text { Patients } \\
(\mathrm{n}=72)\end{array}$ & $\begin{array}{l}\text { Controls } \\
(n=104)\end{array}$ \\
\hline \multicolumn{3}{|l|}{ Genotype } \\
\hline ins/ins & $53.34 \pm 21.53(n=12)$ & $48.29 \pm 20.53(n=23)$ \\
\hline del/del & $47.98 \pm 22.48(n=39)$ & $46.57 \pm 17.98(n=58)$ \\
\hline ins/del & $50.02 \pm 30.88(n=21)$ & $51.04 \pm 28.17(n=23)$ \\
\hline \multicolumn{3}{|l|}{ Alleles } \\
\hline ins & $51.23 \pm 27.53(\mathrm{n}=33)$ & $49.67 \pm 24.42(n=46)$ \\
\hline del & $48.69 \pm 25.49(n=60)$ & $47.84 \pm 21.28(\mathrm{n}=81)$ \\
\hline $\begin{array}{l}\text { TNF- } \alpha(-308 \mathrm{G} / \mathrm{A}) \\
\text { polymorphism }\end{array}$ & Patients $(n=72)$ & Control $(n=104)$ \\
\hline \multicolumn{3}{|l|}{ Genotype } \\
\hline GG & $47.08 \pm 20.00(n=58)$ & $46.77 \pm 21.87(n=84)$ \\
\hline AA & $91.71 \pm 65.08(\mathrm{n}=3)^{* *}$ & $64.78 \pm 1.96(n=2)$ \\
\hline GA & $50.52 \pm 25.82(n=11)$ & $51.55 \pm 16.91(n=18)$ \\
\hline \multicolumn{3}{|l|}{ Alleles } \\
\hline A & $59.35 \pm 38.37(\mathrm{n}=14)^{*}$ & $52.87 \pm 16.51(n=20)$ \\
\hline G & $47.63 \pm 20.86(n=69)$ & $47.61 \pm 27.09(n=102)$ \\
\hline
\end{tabular}

TABLE 4. TNF- $\alpha$ levels according to infectious agent in patients

\begin{tabular}{lc}
\hline Infectious agents & $\begin{array}{c}\text { TNF- } \alpha \text { levels } \\
(\mathrm{pg} / \mathrm{mL})(\mathrm{n}=72)\end{array}$ \\
\hline Candida albicans $(\mathrm{n}=1)$ & 36.72 \\
Acinetobacter baumannii $(\mathrm{n}=27)$ & $53.63 \pm 35.60$ \\
Aspergillus $(\mathrm{n}=1)$ & 47.25 \\
Corynebacterum striatum $(\mathrm{n}=4)$ & $55.72 \pm 22.62$ \\
Pseudomonas aeruginosa $(\mathrm{n}=28)$ & $46.49 \pm 17.58$ \\
Klebsiella pneumoniae $(\mathrm{n}=17)$ & $43.67 \pm 9.53$ \\
Enterobacter $(\mathrm{n}=10)$ & $44.71 \pm 13.14$ \\
Methicillin-resistant Staphylococcus aureus $(\mathrm{n}=19)$ & $42.71 \pm 9.55$ \\
Staphylococcus aureus $(\mathrm{n}=6)$ & $43.27 \pm 8.59$ \\
Serratia marcescens $(\mathrm{n}=1)$ & 71.17 \\
Escherichia coli $(\mathrm{n}=9)$ & $46.59 \pm 16.28$ \\
Vancomycin-resistant Enterococcus $(\mathrm{n}=4)$ & $43.79 \pm 9.96$ \\
Streptococcus pneumoniae $(\mathrm{n}=5)$ & $55.05 \pm 19.75$ \\
\hline TNF- $\alpha$ : tumour necrosis factor-alpha & \\
\hline
\end{tabular}

in the presence of Acinetobacter baumanni, Corynebacterum striatum, Streptococcus pneumonia and Serratia marcescens when compared to infectious agents.

\section{Multivariate logistic regression analysis}

Multivariate logistic regression analysis was also performed and no significant results were found.

\section{DISCUSSION}

The common parameters for the diagnosis of sepsis were redefined in 2005. We observed compatible clinical parameters in the patients (15). In the present study, there was a statistically significant increase for the following parameters in the patient group compared to healthy group: creatinine, BUN, WBC, CRP, lactate, fasting blood glucose, $\mathrm{K}^{+}$, SGPT, SGOT, lactate dehydrogenase levels and body temperature. Two initial molecules in sepsis that need further exploration are TNF- $\alpha$ and interleukin-1 (IL-1). These inflammatory factors associated with severe sepsis are shown by some studies (16-18).

Single nucleotide polymorphisms such as TNF- $\alpha$, IL-1, IL10, and $F c-\gamma$ receptor genes were found to be effective in the regulation of the inflammatory response against microorganisms. Polymorphisms in cytokine genes can affect inflammatory or anti-inflammatory cytokine production and concentrations. Consequently, the patients have either an increased or decreased inflammatory response. It was detected that various genetic polymorphisms, including TNF- $\alpha$, IL-1, IL6 , and IL- 10, were associated with a predisposition to infection and increased mortality in patients with sepsis $(17,18)$. In a GWAS study in premature infants, Srinivasan et al. (19) did not report any significant results for common sepsis genes, such as IL-6, TLR-2, TLR-4, etc.

Previous studies demonstrated that cytokine gene polymorphisms caused severe pneumococcal and meningococcal infections and septic shock (20-22). A Turkish study demonstrated the MyD88 SNP -938 C/C genotype was associated with sepsis (23). Tak and Firestein (22) observed that levels of IL-1 $\beta$, IL-6, and TNF- $\alpha$ proinflammatory proteins in the cell were reduced by suppression of $N F-\kappa B$ dependent inflammation. Additionally, a positive relationship was observed between increased cellular IL- 6 levels and the $N F-\kappa B 1-94$ ins/del ATTG polymorphism deletion allele in a study by Giachelia et al. (24).

In their study comparing carriers of the -308 A allele with GG homozygous individuals in patients with burns, Barber et al. (25) determined that the risk of developing severe sepsis was higher in -308A allele carriers. Song et al. (26) suggested that -308 A was strongly associated with susceptibility to severe sepsis, but not with mortality in the Chinese Han population. 
Feng et al. (27) reported that TNF- $\alpha-308$ A allele and the IL-6 rs1800795 allele variants were risk factors for septic shock induced by pneumonia in intensive care unit patients. Baghel et al. (28) indicated that the TNF- $\alpha-308$ G/A polymorphism was associated with the development of postoperative sepsis and increased expression of TNF- $\alpha$, IL- 6 and IL- 8 genes. Contrary to these studies, we did not find any significant differences between patients and controls according to TNF- $\alpha$ genotype and allele distributions.

In 1993, de Bont et al. (29) reported that in neonatal sepsis IL-6 and TNF- $\alpha$ serum levels increased significantly but IL$1 \beta$ increased only slightly. In addition, in 1994, Ozdemir et al. (30) detected that IL-1 $\beta$ also increased in neonatal sepsis. In 1993, Casey et al. (31) concluded that patients carrying sepsis syndrome criteria, TNF- $\alpha$, IL-1 $\beta$ and IL- 6 levels were high, and there was an inverse correlation between high IL-6 and survival regardless of microbiologic profiles. In 1994, van Deuren et al. (32) specified that in fulminant septicemia, TNF- $\alpha$ levels increased briefly and temporarily for a time in the early stages of infection, but the production of IL- $1 \beta$ was never induced. Kothari et al. (33) reported that plasma TNF- $\alpha$ levels and the single nucleotide polymorphism of the $T N F$ gene showed significant association with the development of severe sepsis and septic shock. Bavunoglu et al. (34) suggested that IL-6, TNF- $\alpha$, NT, and oxLDL serum levels were correlated with the severity of sepsis.

In our study, we compared serum TNF- $\alpha$ levels between the study groups and found increased TNF- $\alpha$ levels statistically insignificant. We suggest that the real importance of TNF- $\alpha$, which is thought to play an important role in the pathogenesis of sepsis, and the periods in which TNF- $\alpha$ plays an active role during the disease should be determined in large population studies. According to TNF- $\alpha$ genotypes and alleles, we observed that TNF- $\alpha$ serum levels in patients carrying TNF- $\alpha$ (-308 G/A) A allele had statistically significant increases compared to those without the A allele. Additionally, TNF- $\alpha$ serum levels in patients carrying TNF- $\alpha$ (-308 G/A) AA genotype showed a statistically significant increase compared to patients carrying GA.

Karban et al. (2) showed that the promoter activity of the $N F-\kappa B 1$-94 del ATTG del allele is considered low, but the promoter activity of the ins allele is considered high. Therefore, the del allele may lead to the production of the p50/p105 NF$\kappa \mathrm{B}$ heterodimer at lower levels and reduce the inflammatory response causing a decrease in $N F-\kappa B 1$ expression.

The $N F-\kappa B 1$-94 ins/del ATTG promoter gene polymorphism was studied and found to also have some immune inflammatory diseases (35). The results obtained from these studies contradict each other as different results were obtained even between experiments that studied the same disease group. These contradictions have been attributed to racial differences (36).
Adamzik et al. (37) found that the NF- $\kappa B 1-94$ ins/del ATTG del allele is associated with an increased 30-day mortality rate in severe sepsis and an increased activation of the innate immune system. In our study, no statistically significant finding was encountered in terms of the $N F-\kappa B 1-94$ ins/del ATTG polymorphism genotype and allele distributions between study groups.

The transcription of TNF- $\alpha$ is performed by NF- $\mathrm{KB}$ (3). Therefore, it is expected that increased NF- $\mathrm{KB}$ activity can cause an increase in TNF- $\alpha$ expression. However, in our study, no significant difference in TNF- $\alpha$ levels was found.

Our findings suggest that there is no relationship between sepsis risk and both polymorphisms; however, the AA genotype and A allele are associated with increased TNF- $\alpha$ levels in patients. As a result, although there have been many innovations in the genetic knowledge and treatment of sepsis, we think that further studies on polymorphisms will be useful, and the data obtained in this study must be supported by further studies with increased patient participation.

Financial Disclosure: İstanbul University Scientific Research Projects Unit supported this study (Project No: 41743).

Conflict of interest: No conflict of interest was declared by the authors.

\section{REFERENCES}

1. Hotchkiss RS, Karl IE. The Pathophysiology and treatment of sepsis. N Engl J Med 2003;348:138-50.

2. Karban AS, Okazaki T, Panhuysen CI, Gallegos T, Potter JJ, Bailey-Wilson JE, et al. Functional annotation of a novel NFKB1 promoter polymorphism that increases risk for ulcerative colitis. Hum Mol Genet 2004;13:35-45.

3. Perkins ND. Integrating cell-signalling pathways with NF-kappaB and IKK function. Nat Rev Mol Cell Biol 2007;8:49-62.

4. Chen F, Castranova V, Shi X, Demers LM. New insights into the role of nuclear factor-kappaB, a ubiquitous transcription factor in the initiation of diseases. Clin Chem 1999;45:7-17.

5. Schäfer ST, Gessner S, Scherag A, Rump K, Frey UH, Siffert W, et al. Hydrocortisone fails to abolish NF- $\mathrm{KB} 1$ protein nuclear translocation in deletion allele carriers of the NFKB1 promoter polymorphism (-94ins/ delATTG) and is associated with increased 30-day mortality in septic shock. PLoS One 2014;9:e104953.

6. Reinhart K, Karzai W. Anti-tumor necrosis factor therapy in sepsis: update on clinical trials and lessons learned. Crit Care Med 2001;29:121-5.

7. Feezor RJ, Oberholzer C, Baker HV, Novick D, Rubinstein M, Moldawer LL, et al. Molecular characterization of the acute inflammatory response to infections with gram-negative versus gram-positive bacteria. Infect Immun 2003;5803-13.

8. Pujhari SK, Ratho RK, Prabhakar S, Mishra B, Modi M. TNF- $\alpha$ promoter polymorphism: a factor contributing to the different immunological and clinical phenotypes in Japanese encephalitis. BMC Infect Dis 2012;12:23.

9. Hillenbrand A, Knippschild U, Weiss M, Schrezenmeier H, HenneBruns D, Huber-Lang M, et al. Sepsis induced changes of adipokines and cytokines - septic patients compared to morbidly obese patients. BMC Surg 2010;10:26. 
10. Mira JP, Cariou A, Grall F, Delclaux C, Losser MR, Heshmati F, et al. Association of TNF2, a TNF-alpha promoter polymorphism, with septic shock susceptibility and mortality: a multicenter study. JAMA 1999;282:561-8.

11. Appoloni O, Dupont E, Vandercruys M, Andriens M, Duchateau J, Vincent JL. Association of tumor necrosis factor-2 allele with plasma tumor necrosis factor-alpha levels and mortality from septic shock. Am J Med 2001;110:486-488.

12. Louis E, Franchimont D, Piron A, Gevaert Y, Schaaf-Lafontaine N, Roland $\mathrm{S}$, et al. Tumour necrosis factor (TNF) gene polymorphism influences TNF-alpha production in lipopolysaccharide (LPS)-stimulated whole blood cell culture in healthy humans. Clin Exp Immunol 1998;113:4016.

13. Zhang M, Zhao Y, Liu Q. Tumor necrosis factor- $\alpha-308 \mathrm{G} / \mathrm{A}$ and $-238 \mathrm{G} / \mathrm{A}$ polymorphisms are associated with increased risks of sepsis: evidence from an updated meta-analysis. APMIS 2017;125:459-67.

14. Bone RC, Balk RA, Cerra FB, Dellinger RP, Fein AM, Knaus WA, et al. Definitions for sepsis and organ failure and guidelines for the use of innovative therapies in sepsis. The ACCP/SCCM Consensus Conference Committee. American College of Chest Physicians/Society of Critical Care Medicine. Chest 1992;101:1644-55.

15. Goldstein B, Giroir B, Randolph A; International Consensus Conference on Pediatric Sepsis. International pediatric sepsis consensus conference: definitions for sepsis and organ dysfunction in pediatrics. Pediatr Crit Care Med 2005;6:2-8.

16. Bernard GR, Vincent JL, Laterre PF, LaRosa SP, Dhainaut JF, LopezRodriguez A, et al. Efficacy and safety of recombinant human activated protein C for severe sepsis. N Eng J Med 2001;344:699-709.

17. Opal SM, DePalo VA. Anti-inflammatory cytokines. Chest 2000;117:116272.

18. O'Dwyer MJ, Mankan AK, Stordeur P, O'Connell B, Duggan E, White M. The occurrence of severe sepsis and septic shock are related to distinct patterns of cytokine gene expression. Shock 2006;26:544-50.

19. Srinivasan L, Page G, Kirpalani H, Murray JC, Das A, Higgins RD, et al. Genome-wide association study of sepsis in extremely premature infants. Arch Dis Child Fetal Neonatal Ed 2017;102:439-45.

20. Somech R, Amariglio N, Spirer Z, Rechavi G. Genetic predisposition to infectious pathogens: a review of less familiar variants. Pediatr Infect Dis J 2003;22:457-61.

21. Emonts M, Hazelzet JA, de Groot R, Hermans PW. Host genetic determinants of Neisseria meningitidis infections. Lancet Infect Dis 2003;3:565-77.

22. Tak PP, Firestein GS. NF-kappaB: a key role in inflammatory diseases. J Clin Invest 2001;107:7-11.

23. Gökay SS, Yıldızdaş RD, Yılmaz M, Aksoy K, Yalın AE, Sertdemir Y, et al. MyD 88 Polymorphisms in Children Diagnosed with Sepsis. Balkan Med J 2016;33:633-8.
24. Giachelia M, Voso MT, Tisi MC, Martini M, Bozzoli V, Massini G, et al. Interleukin-6 plasma levels are modulated by a polymorphism in the NF$\kappa \mathrm{B} 1$ gene and are associated with outcome following rituximab-combined chemotherapy in diffuse large B-cell non-Hodgkin lymphoma. Leuk Lymphoma 2012;53:411-6.

25. Barber RC, Aragaki CC, Rivera-Chavez FA, Purdue GF, Hunt JL, Horton JW. TLR4 and TNF-alpha polymorphisms are associated with an increased risk for severe sepsis following burn injury. J Med Genet 2004;41:808-13.

26. Song Z, Song Y, Yin J, Shen Y, Yao C, Sun Z, et al. Genetic variation in the TNF gene is associated with susceptibility to severe sepsis, but not with mortality. PLoS One 2012;7:46113.

27. Feng B, Mao ZR, Pang K, Zhang SL, Li L. Association of tumor necrosis factor $\alpha-308 \mathrm{G} / \mathrm{A}$ and interleukin-6 $-174 \mathrm{G} / \mathrm{C}$ gene polymorphism with pneumonia-induced sepsis. J Crit Care 2015;30:920-3.

28. Baghel K, Srivastava RN, Chandra A, Goel SK, Agrawal J, Kazmi HR, et al. TNF- $\alpha$, IL-6, and IL- 8 cytokines and their association with TNF- $\alpha-308$ G/A polymorphism and postoperative sepsis. J Gastrointest Surg 2014;18:1486-94.

29. de Bont ES, Martens A, van Raan J, Samson G, Fetter WP, Okken A, et al. Tumor necrosis factor-alpha, interleukin-1 beta, and interleukin-6 plasma levels in neonatal sepsis. Pediatr Res 1993;33:380-3.

30. Ozdemir A, Oygür N, Gültekin M, Coşkun M, Yeğin O. Neonatal tumor necrosis factor, interleukin-1 alpha, interleukin-1 beta, and interleukin-6 response to infection. Am J Perinatol 1994;11:282-5.

31. Casey LC, Balk RA, Bone RC. Plasma cytokine and endotoxin levels correlate with survival in patients with the sepsis syndrome. Ann Intern Med 1993;119:771-8.

32. van Deuren M, van der Ven-Jongekrijg J, Demacker PN, Bartelink AK, van Dalen R, Sauerwein RW, et al. Differential expression of proinflammatory cytokines and their inhibitors during the course of meningococcal infections. J Infect Dis 1994;169:157-61.

33. Kothari N, Bogra J, Abbas H, Kohli M, Malik A, Kothari D, et al. Tumor necrosis factor gene polymorphism results in high TNF level in sepsis and septic shock. Cytokine 2013;61:676-81.

34. Bavunoglu I, Genc H, Konukoglu D, Cicekci H, Sozer V, Gelisgen R, et al. Oxidative stress parameters and inflammatory and immune mediators as markers of the severity of sepsis. J Infect Dev Ctries 2016;10:1045-52.

35. Butt C, Sun S, Peddle L, Greenwood C, Hamilton S, Gladman D, et al. Association of nuclear factor-kappaB in psoriatic arthritis. J Rheumatol 2005;32:1742-4.

36. Borm ME, van Bodegraven AA, Mulder CJ, Kraal G, Bouma G. A NFKB1 promoter polymorphism is involved in susceptibility to ulcerative colitis. Int J Immunogenet 2005;32:401-5.

37. Adamzik M, Schäfer S, Frey UH, Becker A, Kreuzer M, Winning S, et al. The NFKB1 promoter polymorphism (-94ins/delATTG) alters nuclear translocation of NF- $\mathrm{kB} 1$ in monocytes after lipopolysaccharide stimulation and is associated with increased mortality in sepsis. Anesthesiology 2013;118:123-33. 